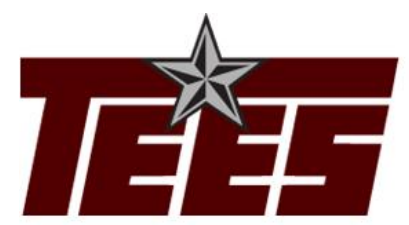

MARY KAY O'CONNOR PROCESS SAFETY CENTER TEXAS A\&M ENGINEERING EXPERIMENT STATION

$18^{\text {th }}$ Annual International Symposium

October 27-29, 2015 - College Station, Texas

\title{
Selection of Failure Frequency and its Impact on Risk Assessment - A Case Study from Plot Plan Optimisation
}

\author{
Mahesh Murthy \\ Process Safety Manager, Maersk Oil GmbH, Building 1, Microdistrict 21, \\ Aktau 130000, Kazakhstan \\ Email:mahesh.murthy@outlook.com \\ Nellya Serikova \\ Safety and Risk Engineer, DNV GL Kazakhstan, Moskva Business Centre, $16^{\text {th }}$ Floor, \\ Office \#3, Dostyk 18, Astana, Kazakhstan, 010000
}

Email: Nellya.Serikova@dnvgl.com

\begin{abstract}
Facility Siting is an important phase of project development. A critical stage is plot plan optimisation, where significant potential hazards are eliminated due to equipment spacing. In addition to ensuring appropriate compliance with minimum spacing requirements, occupied building studies to achieve compliance with the requirements of API 752 and API 753 could also be undertaken to optimise safety outcomes. The studies are done in three stages, where the first stage is hazard identification, second stage is consequence assessment and the third stage is risk assessment. Third stage assessments are only carried, if the consequence based siting recommendations are not practical to implement.

This paper presents the challenges in estimating risk due to process hazards with a focus on selecting right event likelihood data. A comparison is presented on the variation in predicted risk levels based on equipment failure rates and leak frequencies.

Case study of a plot plan optimisation study is undertaken with DNVGL Phast Risk and the variation in risk levels up to two orders of magnitude are recorded. Challenges such as adaption of data for local conditions, consistent definitions of failure, sample size of data, applicability of data play a significant role in identifying and correctly quantifying the risk levels. Such challenges and its impact on risk quantification are presented in this paper as well as its impact on facility siting.
\end{abstract}




\section{Introduction}

Facility Siting is an important stage of layout design. Facility siting allows mitigation of consequences due to fire, toxic and explosion overpressures mainly by locating the equipment in a safe zone. In doing so, there is a structured process for identifying the hazards, estimating the consequences, mitigating the consequences and then where mitigation of consequences is not practical, the scenarios are subject to risk assessment. This is a typical process recommended in the Occupied Building Studies as per American Petroleum Institute (API) Recommended Practice 752[1]. The approach in the recommended practice could be utilised for plot plan optimisation.

Facility siting studies can be applied at various project safety lifecycles. A green-field application yields a different outcome compared to a brownfield modification. In either phase of safety lifecycle, there is a clear distinction of understanding the hazards posed by process and in some cases there has been utilisation of this approach for emergency planning responses [2] to land use planning purposes [3].

Marsh insurance, one of the largest insurers of major hazards facilities, estimates that the total losses due to hydrocarbon releases since 1972 has exceeded in excess of USD10.6 billion [4].This includes incidences that are related to facility siting deficiencies.

\section{Facility siting incidences}

On 19th November 1984, a large Vapour Cloud Explosion at San Juan Ixhuatepec, Mexico City, PEMEX LPG terminal resulted in 650 fatalities and 6400 injuries [5]. Subsequent investigation concluded that there were multiple causal factors including proximity of community to the process areas, disabling of fire water protection due to overpressure post explosion and lack of isolatable segments for reducing the impact of fires. These factors are preventable, if there had been a due process of facility siting.

Subsequent to the BP Texas City Incident that witnessed 15 fatalities and 170 injuries, a renewed focus on placement of occupied buildings followed. API RP 752 and 753 [6] was rigorously enforced worldwide and the Baker Panel report [7] was carefully studied to understand the full implications of hazards impacting occupied buildings.

A lesser known explosion in an oxidisation unit of a petrochemical plant in Chesire UK in 1984 had significant facility siting issues. The resultant fire impacted the fire water capabilities and disrupted critical services such as railways and waterways. The plant was rebuilt with increased plot area to mitigate consequential spacing risks to gain regulatory approvals [8].

Fukushima nuclear disaster followed from the earthquake and tsunami in 2011 highlighted some of the facility siting issues. The emergency diesel reactor failed upon demand, as it was flooded with water after the tsunami thereby leading to power loss with a potential for a core meltdown [9].

Historically, there have been many instances where adequate facility siting studies could have prevented major accident events. This clearly outlines the importance of facility siting. 


\section{Engineering standard, recommended practices and frameworks}

Facility siting and minimum spacing requirements are specified in numerous documents with regulatory authorities worldwide. Some of the governing standards used in oil and gas installations are specified in Process Industry Practices, API 2510 [10] and in particular with API RPT 2510 A ,with a special reference to spacing of vessels, orientation of vessels post Mexico City event. A risk based approach is advised over and above the minimum mandated spacing requirement. There is often a misconception that minimum safety distances makes the layout inherently safe, however, this is not the case. The minimum spacing requirements could be met, however, there could still be risks of knock on effects and hence a risk based approach is recommended.

API 752 and 753 take a more conservative approach. Though the primary intent is to ensure safety of personnel within an occupied building and to ensure that critical infrastructure is protected during emergencies, it is often applied to achieve safe separation and location of plant areas during the design phase of the layout. There is an ever growing focus on eliminating the location based risks at an early phase of project maturation.

NFPA 59 A [11] in the LNG industry bears a good testimony of having an exclusive chapter on Facility Siting based on numerous events where Facility Siting aspects were found to be less than adequate.

A general caution that applies in the context of spacing or facility siting is that there is no prescriptive way of designing. Facility siting challenges are unique to each project and engineering standards, recommended practices and legislated requirements are meant to serve minimum requirements, which must not be taken as an absolute value.

\section{Quantitative Risk Assessment and reliance on equipment failure databases}

Equipment failure could result in "loss of containment" of hydrocarbons, or simply be a "failure of functionality". The initial origin of the equipment failure-frequency concept cannot be accurately determined. However, through published research it is most likely that the early equipment failure data was widely documented in the US nuclear industry dating back to the 1960's and early 1970's [12]. General failure data was published by numerous sources, e.g. Philips and Warwick in 1969 and Smith and Warwick in 1974 [13]. Historical publications on equipment failure frequency data for onshore industrial applications can be traced back to 1978 in a report titled "Canvey- an investigation of potential hazards from operations in the Canvey Island/Thurrock area” (commonly referred as the Canvey Island Report, 1978) [14]. Assessment of equipment failure frequency became the regular norm in QRA processes. A similar approach of publishing equipment failure frequency was adopted in The Netherlands with the release of the COVO report in 1982 (Rijnmond Public Authority, 1982) [15]. Following the Piper Alpha offshore platform disaster in 1988, Lord Cullen's report paved the way for establishing a hydrocarbon leaks database from offshore installations, which is currently maintained by the Health and Safety Executive (UK) (Offshore Hydrocarbon Releases Statistics, 2002) [16]. In 
1994, the Dutch authority first published the standardised failure frequency document called the IPO initiative to be used for QRA purposes [17]. In 1999, the Dutch government published the Purple Book, which detailed equipment failure frequency based on the IPO report (RIVM, CPR 18E, 1999) [18]. At the same time, consolidated efforts by leading petroleum companies paved the way for the Offshore Reliability Database, commonly known as OREDA, which was released in 1984 (OREDA 2009) [19]. OREDA has since then also been widely used for onshore applications. Regulatory reporting has played a significant role in deriving the equipment failure frequency which resulted in a loss of containment of fluids. There are numerous such databases maintained by various regulatory authorities, e.g. E\&P forum maintains a very good pipeline failure database for European applications, while Department of Transport maintains a similar database for US pipelines. Industry representative bodies such as American Petroleum Institute (API), Centre for Chemical Process Safety (CCPS), Institute of Chemical Engineers (IChemE), have published information on equipment data failure. Equipment manufacturers and suppliers have also maintained test result databases and these provide a performance measure for estimating equipment failure.

A wide range of databases containing information on various equipment failure rates are available for public reference. The information has consistently been built up from previous studies, although in most cases the published data cannot be linked back to the source [20] [21]. This has resulted in reliance on the engineering judgement of the individual with far less understanding of the origin of the data. This factor has been recognised in some of the risk assessment software models.

\section{General issues surrounding equipment failure databases}

Equipment failure databases have different and specific intended applications [22]. The databases range from the nuclear industry, aviation/space industries, automotive industries, and numerous component manufacturers. For the purposes of this paper, databases that are generally referred to in the oil and gas industry for QRA purposes have been compared. Off-Shore Reliability Database (OREDA), TNO Purple book, United Kingdom Health and Safety (UK HSE) - Offshore Release Statistics and Centre for Chemical Process Safety/American Institute of Chemical Engineer's (AIChE) - Process Equipment Reliability Database (PERD) have been compared (OGP Report number 434, 2010).

Risk is the product of "likelihood" and "consequence”. Likelihood in the context of QRA largely refers to "equipment failure rates". Theses failure rates, as a general observation, in many companies are obtained from the information in public domain databases.

Databases available in public domain have differences in many areas. The following pitfalls should be avoided while choosing the equipment failure frequency for QRA purposes:

\section{Service condition of the failed equipment}

Plant equipment failure is largely governed by the process conditions during operation. Process conditions could be external or internal to the plant equipment.

A pump may be in hot, cold or in cryogenic service conditions but the failure rate is given equal consideration while inputting into the QRA calculations. In another example, data analyses from relief valve failure indicated that the gas service failure rate was higher than the liquid service. 
Careful consideration should be given to the service conditions while selecting equipment failure rate, as this could alter the risk profiles.

Data sample size for equipment failure data

Sample size of equipment failures is an important indicator of the quality of data that is being used. Often the sample size of the data is overlooked. In certain instances, the database may only have reported the data; however, the sample size may not be significant to meet the reliability confidence levels. In such cases, it is always recommended to approach the equipment manufacturer or derive inference from the plant history. Industry experience and individual judgement also play an important role in making this decision.

\section{Definition of failure}

Failure definitions have varied between the databases. Failure in some cases has been in the context of hydrocarbon loss of containment and in others the loss of functionality. Databases have been driven by regulatory requirements, e.g. UK HSE, and others through voluntary reporting (CCPS and OREDA) as part of good industry practices. Both approaches have merits and drawbacks. As an example, a failed Critical Functionality Test during valve stroke testing may not necessarily lead to hydrocarbon loss of containment and hence definition of failure in this case could be "loss of functionality". A conservative approach would be to carefully evaluate the failure definition in the context of the QRA application.

\section{Failure rate recorded duration}

Failure rate recording is done in many ways. Million hours of operations, annual frequency or variable hours of operations are some common ways of recording frequency of equipment failure. QRA input data has to be consistent in application to project consistent risk levels. A direct correlation through naturalisation of data to a common denominator may not necessarily be the correct approach in many cases. However, it is necessary that frequency is correctly reflected in the input data of the QRA model to give realistic risk estimation. Special attention should be paid while converting the scientific notational data to input data prior to commencing QRA modelling.

\section{Reporting purposes and context}

Reporting can be for regulatory purposes or on a voluntary basis. Regulatory reporting driven databases tend to focus on reporting hydrocarbon loss of containment with the intent of reducing harm to people, property or environment, whereas voluntarily shared data is focused on asset integrity and reliability. QRA data has to be specific to the context under which the study is commissioned. Many companies have over a period of time developed their own internal recording processes and such data represents more realistic risk assessment when applied to plant QRA. Transportability of equipment failure data between various industries and applications has to be carefully analysed and a general trap of using a fudge factor/ modification factors for localising the data should be avoided [23].

General comparisons between databases used in the oil and gas industry are presented in Table 1 below.

\section{A case study of plot plan optimisation}




\section{Project background:}

An expansion project was underway to double the production capacity on a fast track basis. The project involved connecting hundreds of wells through a gathering system, duplication of oil production trains with increasing capacities of three phase separators, heaters, pumps, compressors, oil storage tanks, power plant and a flare system upgrade. The project also intended to install a hydrogen sulphide extraction skid to cater to suspected changes in hydrocarbon stream compositions. The capacity addition was to tie in to an existing producing facility and hence had interfaces with the current plant design.

Minimum separation between the equipment was in accordance with VNTP 3-85 [24] and VUPP 88 [25]. In addition to meeting the minimum separations, there were concerns on spacing of equipment and hence the plot plan was subject to a three stage risk assessment taking the Occupied Building Study approach.

Table 1: General comparison of different databases used in quantitative risk assessments

\begin{tabular}{|c|c|c|c|c|}
\hline $\begin{array}{l}\text { Database } \\
\text { type }\end{array}$ & $\begin{array}{l}\text { UK HCRD } \\
\text { Database }\end{array}$ & $\begin{array}{l}\text { Generic failure } \\
\text { frequency, } \\
\text { Handbook of } \\
\text { frequencies }\end{array}$ & $\begin{array}{l}\text { TNO Purple } \\
\text { book }\end{array}$ & $\begin{array}{l}\text { OREDA } \\
\text { Database }\end{array}$ \\
\hline Base & $\begin{array}{l}\text { UK HSE, UKCS } \\
\text { (Regulatory) }\end{array}$ & $\begin{array}{l}\text { Belgium } \\
\text { (Flemish } \\
\text { region), onshore } \\
\text { (Regulatory) }\end{array}$ & $\begin{array}{l}\text { Netherlands } \\
\text { TNO - Onshore } \\
\text { (Regulatory), }\end{array}$ & $\begin{array}{l}\text { North Sea } \\
\text { Offshore } \\
\text { installations, } \\
\text { PSA,NCS } \\
\text { (Voluntary) }\end{array}$ \\
\hline Leak events & $\begin{array}{l}\text { - } 20 \text { years } \\
\text { - Over } 4000 \text { leak } \\
\text { events } \\
\text { - } 78 \text { different } \\
\text { types equipment } \\
\text { - } 17 \text { equipment } \\
\text { types }\end{array}$ & $\begin{array}{l}\text { - From } 1981 \\
\text { - Based on } \\
\text { Smith } \\
\text { \&Warwick } \\
\text { data }\end{array}$ & - Local data & $\begin{array}{ll}- & \text { From } 1981 \\
\text { - } & 265 \\
& \text { installations } \\
\text { - } & 16000 \\
& \text { equipment } \\
& \text { units } \\
\text { - } & 38000 \text { failure } \\
& \text { registered } \\
\text { - } & 68000 \\
& \text { maintenance } \\
\text { records }\end{array}$ \\
\hline Failure type & $\begin{array}{l}\text { Loss Of } \\
\text { Containment }\end{array}$ & General failure & $\begin{array}{l}\text { Loss Of } \\
\text { Containment }\end{array}$ & $\begin{array}{l}\text { Loss of equipment } \\
\text { from }\end{array}$ \\
\hline Equipment & $\begin{array}{l}\text { Data available for } \\
\text { all type of } \\
\text { equipment }\end{array}$ & $\begin{array}{l}\text { No data for } \\
\text { flanges, } \\
\text { instrumentation, } \\
\text { valves }\end{array}$ & $\begin{array}{l}\text { No data for } \\
\text { flanges, } \\
\text { instrumentation, } \\
\text { valves }\end{array}$ & $\begin{array}{l}\text { No data for } \\
\text { flanges, } \\
\text { instrumentation, } \\
\text { inter unit pipes }\end{array}$ \\
\hline Hole & Well defined & Generally & Generally & Not defined \\
\hline
\end{tabular}




\begin{tabular}{|l|l|l|l|l|}
\hline $\begin{array}{l}\text { sizes/leak } \\
\text { rates }\end{array}$ & & defined & defined & \\
\hline $\begin{array}{l}\text { Service } \\
\text { condition } \\
\text { defined }\end{array}$ & Yes & No & No & No \\
\hline
\end{tabular}

\section{Study methodology}

The study methodology involved a three phase approach:

\section{Stage 1 - Hazard identification - identifying credible hazards}

In establishing credible hazard scenarios, a multi engineering discipline workshop was commissioned. Plant equipment location, inventory, stream compositions, process conditions, failure mechanisms, wind directions and consequence impact of fire, explosion and toxicity on adjacent installations were accounted in deriving credible hazardous scenarios. At this stage there was no credit taken for any controls and/or efficacy of controls in place. "What-If" analysis led to identification of multiple scenarios that could lead to major accident event.

\section{Stage 2 - Consequence assessment}

Credible hazard scenarios were then examined closely for process conditions, inventories and isolatable segments. $20 \mathrm{~mm}$ and $100 \mathrm{~mm}$ leak sizes were applied (with an exception to toxic release scenarios where more conservative hole sizes were modelled; however, this is not presented in the case study) for the consequence assessment using DNVGL Phast software. Consequences for fire and overpressure were determined. Underpinning consequence contributory factors like jet fire, pool fire, overpressure and toxicity were determined. The consequence acceptance criteria set by the company standards were used to establish safe separation distances and restricted areas.

\section{Stage 3 - Risk assessment}

The consequence approach on facility siting was adopted for the expansion project and those equipment that had difficulties in meeting the consequence based separation distances were then subject to the risk based separation distances approach. The risk based approach took into account equipment failure likelihood to establish safe separation distances.

Case studies represented in this paper relate to the expansion project phase.

Case study of first and second stage separators stacking versus horizontal separation arrangement

\section{Process description}

Fluid from inlet bulk fluid Heat Exchangers is routed to $1^{\text {st }}$ stage separator. $1^{\text {st }}$ stage separator operates at 5 barg pressure. $1^{\text {st }}$ stage separator is a 3-phase separator from which the gas goes to compressor, water to produced water treatment and oil routed to 2nd stage separator. 2nd stage separator operates at an operating pressure of about 0.3 barg pressure. 2nd Stage Separator is 
also a 3-phase separator. Crude oil is stored in oil export tank. The process conditions of the separators are shown in Table 2 below.

Table 2 - Process conditions of separators

\begin{tabular}{|c|c|c|c|c|c|c|}
\hline $\begin{array}{c}\text { Scenari } \\
\text { o }\end{array}$ & Phase & $\begin{array}{c}\text { Pressure } \\
\text {, bar } \\
\text { atm }\end{array}$ & $\begin{array}{c}\text { Temperatur } \\
\text { e, } \\
\text { Deg C } \\
\end{array}$ & $\begin{array}{l}\text { Composition } \\
\text {, (mol.) }\end{array}$ & $\begin{array}{c}\text { Inventory } \\
\text {, kg }\end{array}$ & Hazards \\
\hline $\begin{array}{l}\text { 1st stage } \\
\text { separator }\end{array}$ & $\begin{array}{l}\text { Gas + } \\
\text { Liquid }\end{array}$ & 6 & 60 & $\begin{array}{c}19.8 \% \mathrm{C} 1 \text {, } \\
8.4 \% \mathrm{C} 2, \\
7.7 \% \mathrm{C} 3 \text {, } \\
5.9 \%-\mathrm{C} 4 \\
\text { 4.2\%-C5, } \\
53.3 \%-\mathrm{C} 6+\end{array}$ & 78041 & 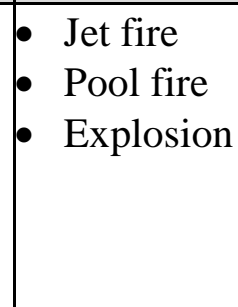 \\
\hline $\begin{array}{l}\text { 2nd } \\
\text { stage } \\
\text { separator }\end{array}$ & $\begin{array}{l}\text { Gas + } \\
\text { Liquid }\end{array}$ & 1 & 56 & $\begin{array}{c}2.2 \% \text { C1, } \\
3.1 \% \text { C2, } \\
5.8 \% \text { C3, } \\
6.9 \% \text { C4, } \\
6.5 \% \text { C5, } \\
75.5 \% \text { C6+ }\end{array}$ & 39223 & \\
\hline
\end{tabular}

Figure 1, 2 and 3 represent the first vessel arrangements in stacking mode and in horizontal separation mode. In the stacking mode the modelling is done with a release height of $1 \mathrm{~m}$ and $4 \mathrm{~m}$ from the ground level. In the case of horizontal separated arrangement a $15 \mathrm{~m}$ separation is modelled from the edge of the vessel diameter.

15m separation is based on Table 1 of NISTIR 6546, research report of the Building and Fire Research Laboratory. This research is on thermal radiations from large pool fires [26].

In all cases 20 and $100 \mathrm{~mm}$ hole sizes were modelled for consequence estimates. Risk modelling was done by taking the equipment failure data from UK HSE, Belgian data, TNO Purple Book and OREDA. 
Figure1: Stacked arrangement - front view

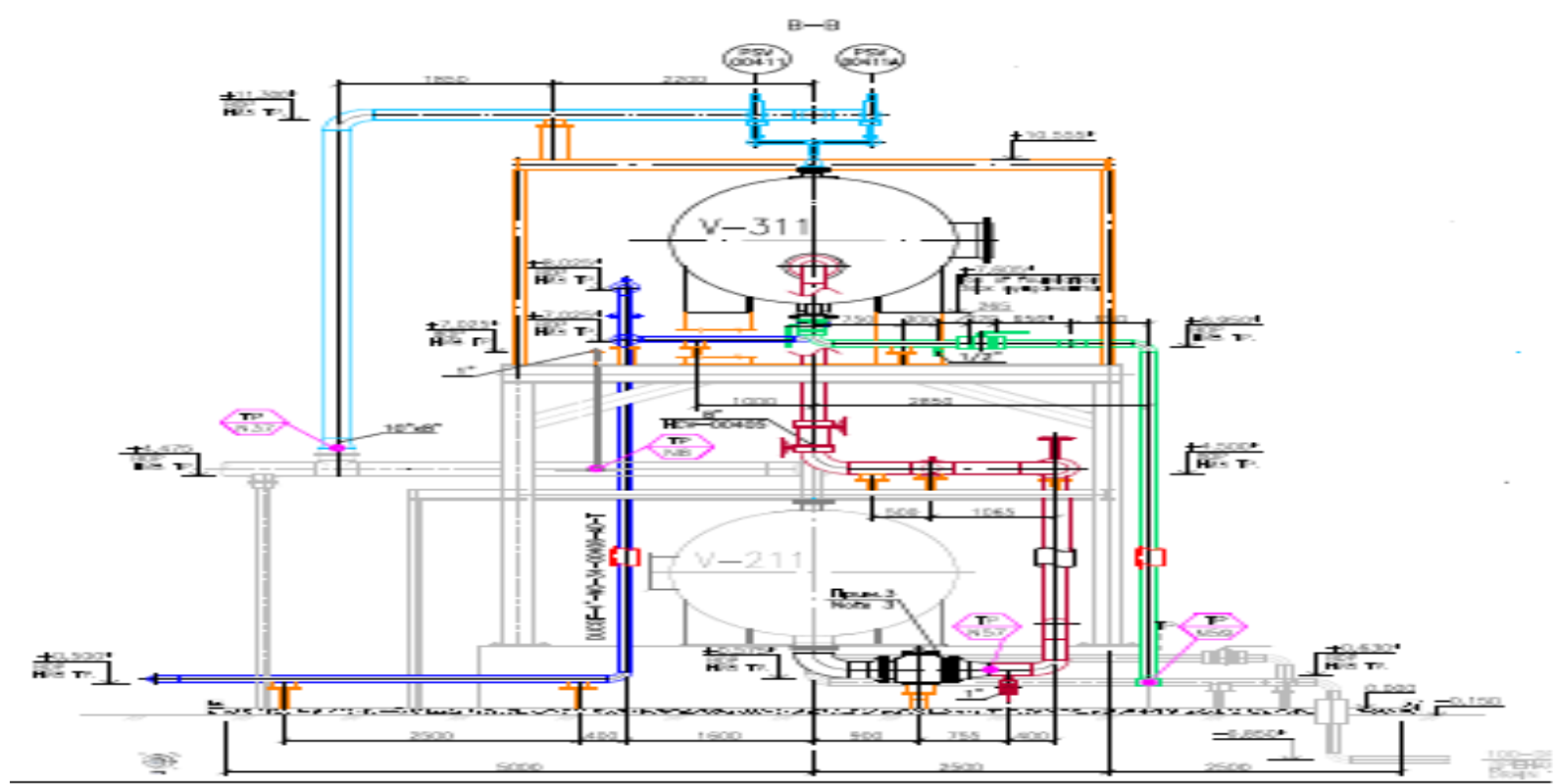

Figure2: Stacked arrangement - side view

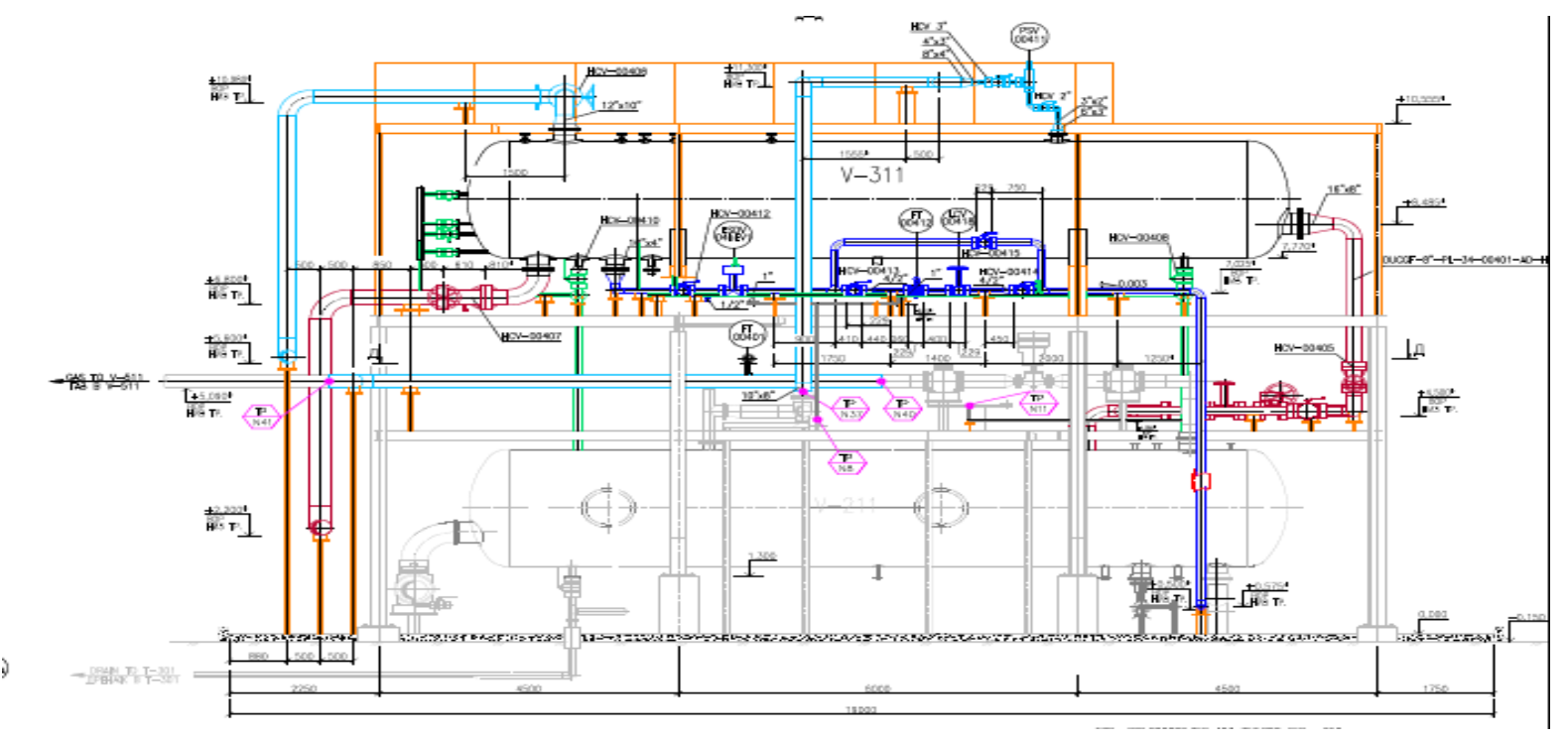




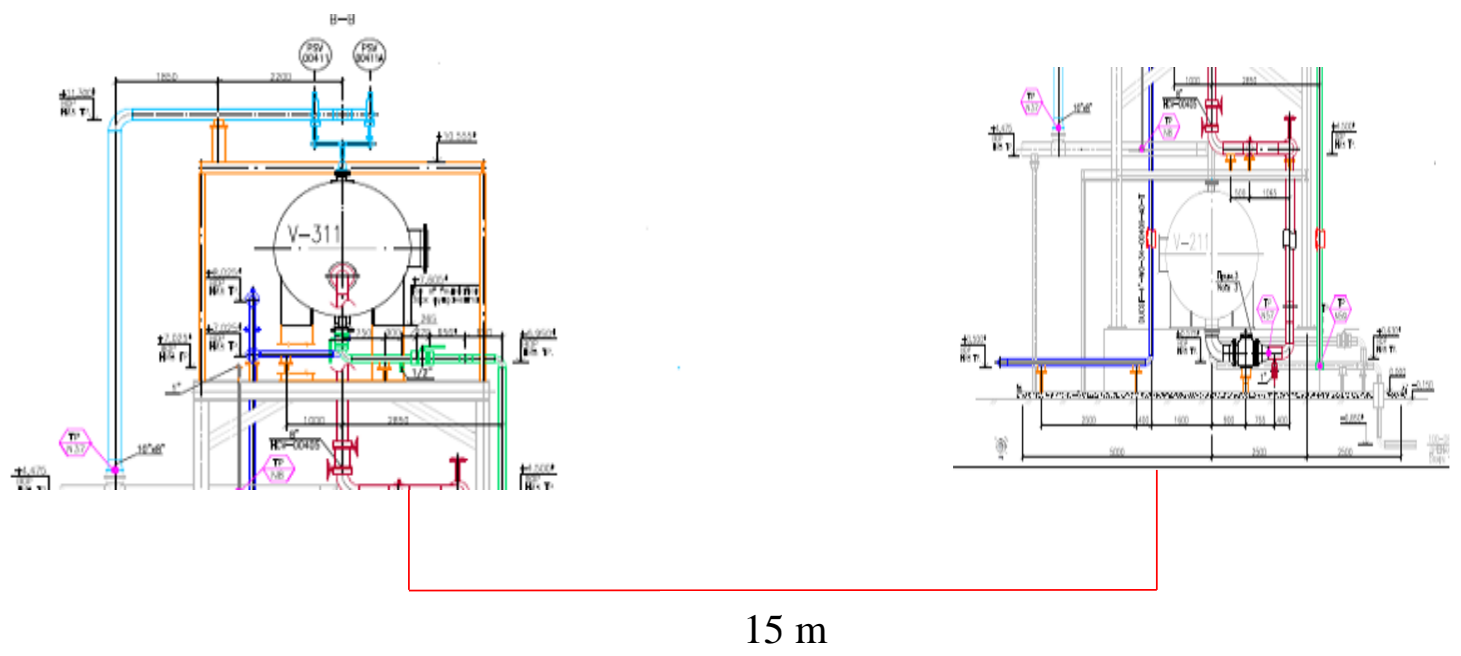

Figure 3: Horizontal separation - front view

\section{Modelling methodology}

A two stage modelling methodology was introduced after identifying the worst case credible hazards. The first stage was consequence based modelling, where $20 \mathrm{~mm}$ and $100 \mathrm{~mm}$ leaks were modelled. Consequence based separations distances and its impact on spacing were also modelled.

Subsequently, risk based modelling approach with equipment failure rates were modelled. During the risk based modelling, failure rates for different databases were used and the end risk levels were compared. Maintenance factors were introduced on risk levels to understand the variation in the risk levels. This approach is further explained in detail below.

Consequence modelling was undertaken for $20 \mathrm{~mm}$ and $100 \mathrm{~mm}$ hole size distribution for stacked arrangement and separation type arrangement. Separation distances due to leaks of 20mm and $100 \mathrm{~mm}$ hole sizes were modelled based on heat radiation end point of $9.5 \mathrm{kw} / \mathrm{m}^{2}$, flammability end point (LFL) of 30697 ppm and 20970 ppm for $1^{\text {st }}$ and $2^{\text {nd }}$ stage separators, respectively, and explosion end points of $0.14 \mathrm{mbar}$ and $0.2 \mathrm{mbar}$. Safety distance was identified based on the consequence end point for a 20mm hole size and Restricted Access distance was identified based on consequence end point for 100mm hole size. The distances are shown in Table3

An equipment failure rate was introduced to the first and second stage separator and the failure rates using different databases were compared. The risk levels are presented in Table 4 and Table 5. The risk contours using different databases are represented in Figure 5. Maintenance factor of 2 is also applied to look at the effect of the maintenance in reducing risks. Maintenance factors are indicators of maintenance carried out on the equipment. This is represented in Table 6. Risk levels in isolation and when compared in context i.e. cumulative risk is presented in Table 7. Heat radiation effect on stacked vessel arrangements versus horizontally separated vessels at $15 \mathrm{~m}$ and $28 \mathrm{~m}$ distances are represented in Table 8 . The risk contours of stacked versus horizontally separated vessels are presented in Figure 6. 
Table 3: Comparing separation distances for stacked vessel versus horizontally separated vessels, $\mathbf{m}^{1}$

\begin{tabular}{|c|c|c|c|c|c|c|c|c|c|c|c|}
\hline \multirow{2}{*}{\multicolumn{2}{|c|}{\begin{tabular}{|l} 
\\
Heat radiation
\end{tabular}}} & \multirow{4}{*}{\begin{tabular}{l}
\multicolumn{1}{c}{$\begin{array}{c}\text { Stacked } \\
\text { arrangeme } \\
\text { nt }\end{array}$} \\
Release \\
direction \\
horizontal \\
impingemen \\
$\mathrm{t}$ due to \\
obstruction, \\
$1^{\text {st } \text { stage }}$ \\
separator at \\
1 m height, \\
2 nd stage \\
separator at \\
4 m height
\end{tabular}} & \multicolumn{2}{|c|}{$\begin{array}{c}\text { I stage } \\
\text { separator }\end{array}$} & \multicolumn{2}{|c|}{$\begin{array}{c}\text { II stage } \\
\text { separator }\end{array}$} & \multirow{3}{*}{\begin{tabular}{|l}
$\begin{array}{c}\text { Horizontal } \\
\text { separation } \\
\text { arrangeme } \\
\text { nt }\end{array}$ \\
$\begin{array}{l}\text { Release } \\
\text { horizontally } \\
\text { directed, } \\
\text { both } \\
\text { separators } \\
\text { are at } 1 \mathrm{~m} \\
\text { height }\end{array}$ \\
\end{tabular}} & \multicolumn{2}{|c|}{$\begin{array}{c}\text { I stage } \\
\text { separato } \\
\text { r }\end{array}$} & \multicolumn{2}{|c|}{$\begin{array}{l}\text { II stage } \\
\text { separator }\end{array}$} \\
\hline & & & $\begin{array}{l}20 \\
\mathbf{m}\end{array}$ & $\begin{array}{l}100 \\
\mathbf{m m}\end{array}$ & $\begin{array}{l}20 \\
\mathbf{m}\end{array}$ & $\begin{array}{l}100 \\
\mathrm{~mm}\end{array}$ & & $\begin{array}{l}20 \\
\mathbf{m}\end{array}$ & $\begin{array}{l}\mathbf{1 0} \\
\mathbf{0} \\
\mathbf{m}\end{array}$ & $\begin{array}{l}20 \\
\mathrm{~mm}\end{array}$ & $\begin{array}{l}100 \\
\mathbf{~ m m}\end{array}$ \\
\hline \multirow{2}{*}{$\begin{array}{ll}\text { - } & \text { Jet fire } \\
\text { - } & \text { Pool } \\
& \text { fire } \\
\text { - } & \text { Flash } \\
& \text { fires }\end{array}$} & $\begin{array}{l}\text { Jet fire } \\
(9.46 \\
\mathrm{kW} / \mathrm{m} 2 \\
)\end{array}$ & & 5.6 & 38.5 & NR & 36.2 & & $\begin{array}{l}12 . \\
9\end{array}$ & $\begin{array}{l}66 . \\
5 \\
\end{array}$ & 13.5 & 69.4 \\
\hline & $\begin{array}{l}\text { Pool } \\
\text { fire } \\
(9.46 \\
\mathrm{kW} / \mathrm{m} 2 \\
)\end{array}$ & & $\begin{array}{l}26 . \\
4\end{array}$ & 48.2 & $\begin{array}{l}26 . \\
2\end{array}$ & 59.4 & & $\begin{array}{l}26 . \\
4\end{array}$ & $\begin{array}{l}48 . \\
2\end{array}$ & 26.2 & 59.4 \\
\hline \begin{tabular}{|l} 
Flammabili \\
ty
\end{tabular} & LFL & & $\begin{array}{l}14 . \\
0\end{array}$ & 137.2 & $\begin{array}{l}10 . \\
3\end{array}$ & 69.1 & & 6.7 & $\begin{array}{l}51 . \\
2\end{array}$ & 7.2 & 51.4 \\
\hline \multirow{2}{*}{$\begin{array}{l}\text { Overpressu } \\
\text { re }\end{array}$} & $\begin{array}{l}0.14 \\
\text { mbar }\end{array}$ & & $\begin{array}{l}\text { 14. } \\
1\end{array}$ & 97.2 & $\begin{array}{l}12 . \\
3 \\
\end{array}$ & 66.4 & & 7.5 & $\begin{array}{l}46 . \\
2\end{array}$ & 7.5 & 37.1 \\
\hline & $\begin{array}{l}0.2 \\
\mathrm{mbar}\end{array}$ & & $\begin{array}{l}10 . \\
6\end{array}$ & 72.7 & 9.2 & 49.7 & & 5.6 & $\begin{array}{l}34 . \\
6\end{array}$ & 5.6 & 27.8 \\
\hline \multicolumn{2}{|c|}{ LSIR (1E-4 per year) } & 31 & & 22 & & 30 & 45 & & & & \\
\hline
\end{tabular}

Table 4: Risk levels of I stage separators - comparison using different equipment failure rates, [per year]

\begin{tabular}{|c|c|c|c|c|c|}
\hline 1st stage separator & $\begin{array}{c}\text { Equipment } \\
\text { count }\end{array}$ & $\begin{array}{c}\text { UK } \\
\text { HCRD }\end{array}$ & $\begin{array}{c}\text { Generic failure } \\
\text { frequency, Handbook } \\
\text { of frequencies } \\
\text { (Belgian) }\end{array}$ & $\begin{array}{l}\text { Purple book, } \\
\text { Netherlands }{ }^{2}\end{array}$ & OREDA $^{3}$ Database \\
\hline Total per year & & 2.25E-02 & 2.65E-03 & $2.80 \mathrm{E}-04$ & 1.12E-02 \\
\hline Flanges & 21 & 3.03E-03 & NA & NA & NA \\
\hline Pipe process & 100 & $6.57 \mathrm{E}-03$ & 2.36E-03 & $6.00 \mathrm{E}-05$ & NA \\
\hline
\end{tabular}

\footnotetext{
${ }^{1}$ The highest risk results for the weather stability of $2 \mathrm{~F}$ and $5 \mathrm{D}$

${ }^{2}$ Purple book, Netherlands do not have service type distribution.

${ }^{3}$ OREDA Database data used for process vessels and valves for failures types where it is defined as external leakage for process meduim. However it should be noted that OREDA databse does not provide information such as phase, hole size distribution.
} 


\begin{tabular}{|l|c|c|c|c|c|}
\hline Small bore fittings & 7 & $4.13 \mathrm{E}-03$ & NA & NA & NA \\
\hline Valve actuator & 7 & $3.98 \mathrm{E}-03$ & NA & NA & $2.35 \mathrm{E}-03$ \\
\hline Valve manual & 3 & $4.43 \mathrm{E}-04$ & NA & NA & NA \\
\hline Vessel process & 2 & $4.31 \mathrm{E}-03$ & $2.90 \mathrm{E}-04$ & $2.20 \mathrm{E}-04$ & $8.89 \mathrm{E}-03$ \\
\hline
\end{tabular}

Table 5: Risk levels of II stage separators - comparison using different equipment failure rates, [per year]

\begin{tabular}{|l|c|c|c|c|c|}
\hline $\begin{array}{l}\text { 2nd stage } \\
\text { separator }\end{array}$ & $\begin{array}{c}\text { Equipment } \\
\text { count }\end{array}$ & $\begin{array}{c}\text { UK } \\
\text { HCRD }\end{array}$ & $\begin{array}{c}\text { Generic failure } \\
\text { frequency, } \\
\text { Handbook of } \\
\text { frequencies (Belgian) }\end{array}$ & $\begin{array}{c}\text { Purple } \\
\text { book } \\
\text { Borror! } \\
\text { defined. } \\
\text { Netherlands }\end{array}$ & $\begin{array}{c}\text { Nethed } \\
\text { OREDA Error! } \\
\text { Bookmark not } \\
\text { defined. } \\
\text { Database }\end{array}$ \\
\hline Total per year & & $1.49 \mathrm{E}-02$ & $4.79 \mathrm{E}-04$ & $2.39 \mathrm{E}-04$ & $1.09 \mathrm{E}-02$ \\
\hline Flanges & 19 & $2.54 \mathrm{E}-03$ & NA & NA & NA \\
\hline Pipe process & 8 & $5.41 \mathrm{E}-04$ & $1.89 \mathrm{E}-04$ & $1.92 \mathrm{E}-05$ & NA \\
\hline Small bore fittings & 6 & $3.54 \mathrm{E}-03$ & NA & NA & NA \\
\hline Valve actuator & 6 & $3.50 \mathrm{E}-03$ & NA & NA & $2.02 \mathrm{E}-03$ \\
\hline Valve manual & 3 & $4.43 \mathrm{E}-04$ & NA & NA & NA \\
\hline Vessel process & 2 & $4.31 \mathrm{E}-03$ & $2.90 \mathrm{E}-04$ & $2.20 \mathrm{E}-04$ & $8.89 \mathrm{E}-03$ \\
\hline
\end{tabular}

Table 6: Risk levels using different databases

\begin{tabular}{|l|c|c|c|}
\hline Databases & $\begin{array}{l}\text { Leak frequencies of } \\
\mathbf{1}^{\text {st }} \text { and 2 } \mathbf{2}^{\text {st }} \text { stage } \\
\text { separators, /year }\end{array}$ & $\begin{array}{l}\text { IR Integral using } \\
\text { Maintenance Factor } \\
\mathbf{1}\end{array}$ & $\begin{array}{l}\text { IR Integral using } \\
\text { Maintenance Factor } \\
\text { 2 }\end{array}$ \\
\hline UK HSE & $3.73 \mathrm{E}-02$ & $1.13 \mathrm{E}-03$ & $2.26 \mathrm{E}-03$ \\
\hline OREDA & $2.22 \mathrm{E}-02$ & $6.66 \mathrm{E}-04$ & $1.33 \mathrm{E}-03$ \\
\hline Belgium & $3.13 \mathrm{E}-03$ & $2.23 \mathrm{E}-05$ & $4.45 \mathrm{E}-05$ \\
\hline $\begin{array}{l}\text { Purple Book } \\
\text { (TNO) }\end{array}$ & $5.19 \mathrm{E}-04$ & $1.72 \mathrm{E}-05$ & $3.44 \mathrm{E}-05$ \\
\hline
\end{tabular}




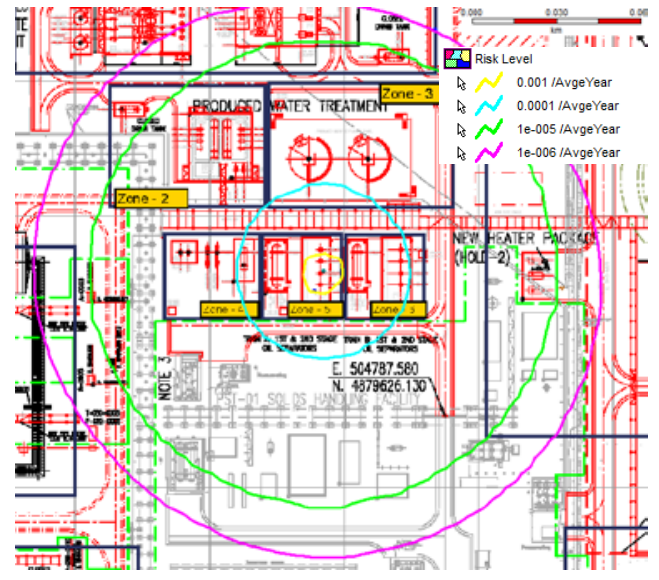

UK

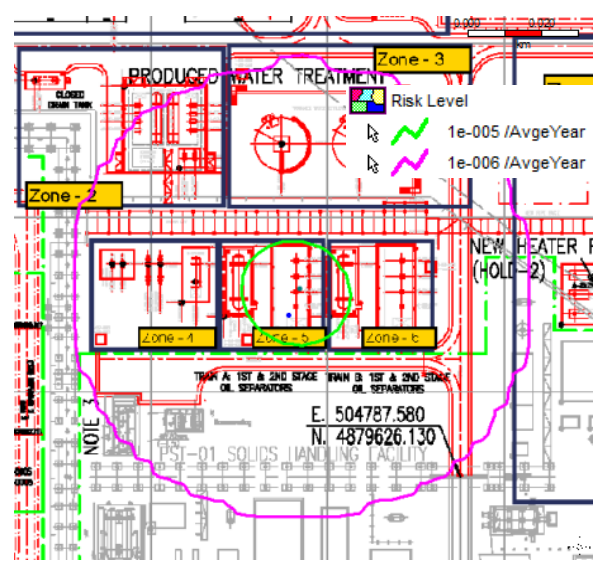

Belgian Handbook of frequencies

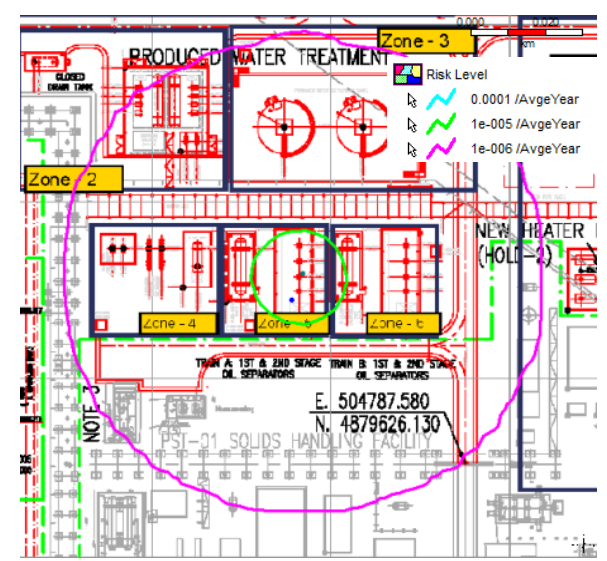

\section{OREDA}

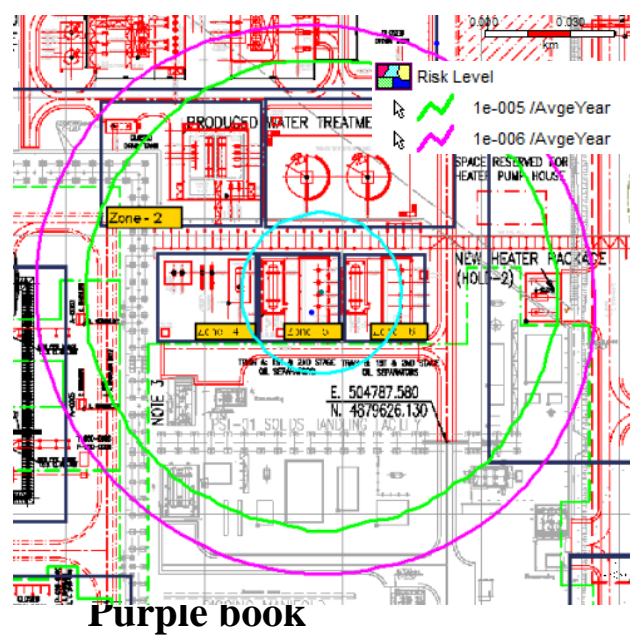

Figure 5: Risk contours with various databases

Table 7: Risk value for standalone vessel versus cumulative risk (in context)

\begin{tabular}{|l|c|c|}
\hline Risk values & $\begin{array}{c}\text { Stacked } \\
\text { arrangement }\end{array}$ & $\begin{array}{c}\text { Horizontal } \\
\text { separation } \\
\text { arrangement }\end{array}$ \\
\hline Risk level in isolation (Process vessel only) & $2.96 \mathrm{E}-04$ & $2.93 \mathrm{E}-04$ \\
\hline Cumulative risk ( risk in context ) & $1.13 \mathrm{E}-03$ & $1.12 \mathrm{E}-03$ \\
\hline Risk differential & $8.34 \mathrm{E}-04$ & $8.27 \mathrm{E}-04$ \\
\hline
\end{tabular}


Table 8: Heat radiation level at different distances

\begin{tabular}{|c|c|c|c|c|c|c|c|c|}
\hline \multirow{3}{*}{$\begin{array}{l}\text { Separation } \\
\text { distance }\end{array}$} & \multicolumn{4}{|c|}{ 1st stage separator } & \multicolumn{4}{|c|}{ 2nd stage separator } \\
\hline & \multicolumn{2}{|c|}{ Jet fire, $\mathrm{kW} / \mathrm{m} 2$} & \multicolumn{2}{|c|}{ Pool fire, kW/m2 } & \multicolumn{2}{|c|}{ Jet fire, $\mathrm{kW} / \mathrm{m} 2$} & \multicolumn{2}{|c|}{ Pool fire, $k W / m_{2}$} \\
\hline & $\begin{array}{l}20 \\
\mathbf{m m}\end{array}$ & $\begin{array}{l}100 \\
\mathbf{m m}\end{array}$ & $20 \mathrm{~mm}$ & $100 \mathrm{~mm}$ & $20 \mathrm{~mm}$ & $\begin{array}{l}100 \\
\mathrm{~mm}\end{array}$ & $20 \mathrm{~mm}$ & $\begin{array}{l}100 \\
\mathrm{~mm}\end{array}$ \\
\hline $\begin{array}{l}3 \mathrm{~m} \text { (Stacked } \\
\text { Arrangement })\end{array}$ & 14 & 4 & $\begin{array}{c}\text { engulfe } \\
\mathrm{d}\end{array}$ & engulfed & 6.8 & 22 & $\begin{array}{c}\text { engulfe } \\
\mathrm{d}\end{array}$ & $\begin{array}{c}\text { engulfe } \\
\mathrm{d}\end{array}$ \\
\hline $\begin{array}{l}15 \mathrm{~m} \\
\text { (Horizontal } \\
\text { Arrangement) }\end{array}$ & 1 & 94 & 20 & engulfed & 0.1 & 69 & 21 & $\underset{\mathrm{d}}{\text { engulfe }}$ \\
\hline $\begin{array}{l}28 \mathrm{~m} \\
\text { (Alternative } \\
\text { arrangement) }\end{array}$ & 0.1 & 14 & 7 & 11 & 0.1 & 1 & 3 & 12 \\
\hline
\end{tabular}

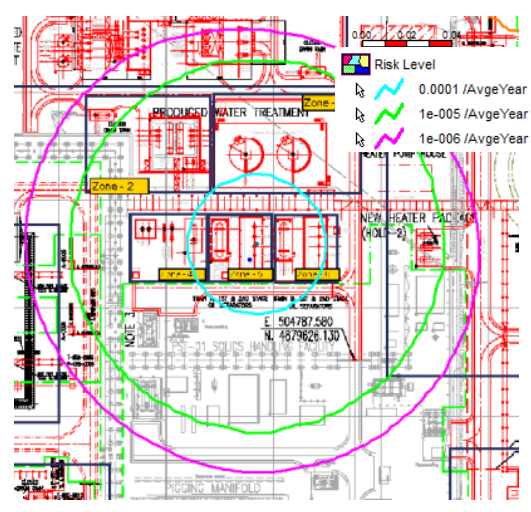

1. Stacked arrangement

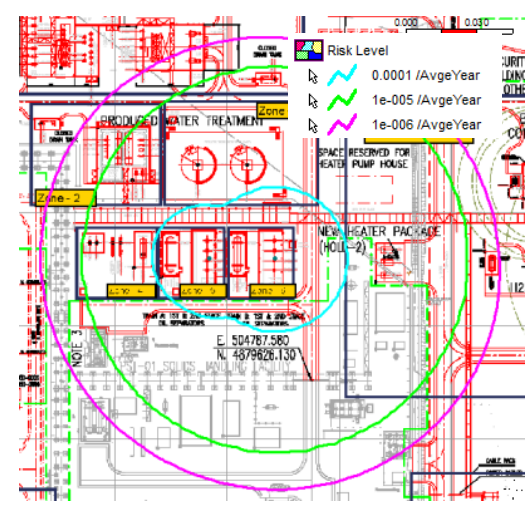

2. Horizontal separation arrangement (28m apart)

Figure 6: Stacked arrangement vs. Horizontal separation arrangement for $1^{\text {st }}$ and $2^{\text {nd }}$ stage separators LSIR contours 


\section{Case study 2: Natural Gas to Liquid (NGL) injection pump relocation}

Natural Gas to Liquid (NGL) under high compression is injected through a pump into the ground operating at 198bar gauge pressure. NGL due to its high pressure has a potential to fire, upon ignition.

A consequence based approach of modelling the scenario using $20 \mathrm{~mm}$ and $100 \mathrm{~mm}$ loss of containment resulted in jet fire scenario of $280 \mathrm{~m}$. A risk based approach resulted in a separation distance of $18 \mathrm{~m}$. The distances are represented in Table 9 below.

In this instance, consequence based separation distance was opted, as it was practical and safe thing to do.

Table 9: NGL pump consequence and risk based distances.

\begin{tabular}{|l|c|c|c|c|}
\hline & \multicolumn{4}{|c|}{ NGL injection pump } \\
\cline { 2 - 5 } & $\begin{array}{c}\text { Jet fire } \\
\mathbf{( 9 . 4 6} \\
\mathbf{k W / m 2})\end{array}$ & $\begin{array}{c}\text { Flammable } \\
\mathbf{( L F L )}\end{array}$ & $\begin{array}{c}\text { Overpressure } \\
\mathbf{( 0 . 2} \text { mbar) }\end{array}$ & $\begin{array}{c}\text { LSIR } \\
\mathbf{( 1 E - 4 )}\end{array}$ \\
\hline $20 \mathrm{~mm}$ & 72.1 & 70.8 & 43.0 & - \\
\hline $100 \mathrm{~mm}$ & 287.0 & 429.4 & 221.7 & - \\
\hline $\begin{array}{l}1 \mathrm{E}-4 \quad \text { per } \\
\text { year }\end{array}$ & 18 & $\mathrm{NR}$ & $\mathrm{NR}$ & 20 \\
\hline
\end{tabular}

\section{Results and discussions}

Facility Siting considerations need to be carefully evaluated as this could have enormous safety consequences in addition to commercial losses. In the case of stacked arrangement of separators, consequences due to fire and explosion were significantly higher compared to horizontally separated design. In this case, it could be clearly established that meeting minimum spacing standard of $15 \mathrm{~m}$ does not necessarily make a safe choice of separation. In this instance a $28 \mathrm{~m}$ distance would render the separators safe. Risk based decisions need to be carefully selected, as it is reliant on the quality of equipment failure data. Failure rate influences risk results in the order of one to two magnitudes. This in real terms has commercial value associated due to increased plot plan areas.

In the case of NGL pump relocation, plot plan was permissive of consequence based distances to be met. If in the event of plot plan constraints, this would have triggered risk based distances being applied, which would have seen emphasis placed on mitigating higher overpressures and heat radiation levels, thereby increasing in costs of engineering controls being put in place.

\section{Learnings}

\section{Direct learnings:}

- Apply consequence based approach and then go with risk based decision making process demonstrating adequacy of controls and risk levels As Low As Reasonably Practicable (ALARP) 
- Use fit for purpose likelihood data of equipment failure and thoroughly understand the variation in risk levels.

- Undertake sensitive studies with credible scenarios to derive at a realistic risk levels, failure of which could result in controls being directed in wrong areas with a possibility of cost escalations.

- Use of maintenance factors or any localisation of data for equipment failure rates has to be adequately justified and its impact fully understood.

\section{Related learnings:}

- Risk from a scenario should be looked in context (cumulative risk) rather than in isolation or stand-alone mode.

- Timing of the plot plan optimisation -facility siting studies derive best value at front end engineering design stage prior to freezing of plot plan. Sufficient time should be allowed for implementing recommendations of the facility siting studies

- If the plant is in operational phase, emphasis on iterative models looking at reducing the inventories through isolatable segments, valve closure times for quick isolation, staggered blow down, and enhancements in engineering control can be derived through the results of facility siting studies.

- Safety zones during normal operations and maintenance can also be established. This could include occupancy distribution studies, access during normal and emergency phases and placement of safety critical services like fire hydrants, flare lines and utilities.

\section{References}

1. American Petroleum Industry, 2009, Management of Hazards Associated with Location of Process Plant Permanent Buildings - Recommended Practice 752, Third Edition

2. Georgiadou PS, et.al, 2006, Modeling emergency evacuation for major hazard industrial sites, Journal of Reliability and System Safety

3. Valero Cozzani, et.al , 2005, Application of land-use planning criteria for the control of major accident hazards: A case study, Journal of Hazardous Materials, A 136, pp 170180Land

4. Marsh Insurance, 2014, The Hundred Largest Losses 1974-2013, Large Property Damage Losses in Hydrocarbon Industry, 23 ${ }^{\text {rd }}$ Edition [Accessed July 25 2015]

5. Lees, F.P., 'Loss Prevention in the Process Industries - Hazard Identification, Assessment and Control', Volume 3, Appendix 4, Butterworth Heinemann,ISBN 07506 1547 8, 1996

6. American Petroleum Industry, 2007, Management of Hazards Associated With Location of Process Plant Portable Buildings - Recommended Practice 753, First Edition

7. Baker Panel Report, 2007, www.csb.gov [Accessed July 25 2015]

8. Cheshire report, www.hse.gov.uk [Accessed July 25 2015]

9. Elizabeth Krausmann, 2013, Impact of the 11 March 2011, Great East Japan earthquake and tsunami on the chemical industry, Volume 67, Issue 2, pp-811-828

10. American Petroleum Industry, 1996, Fire-Protection Considerations for the Design and Operation of Liquefied Petroleum Gas (LPG) Storage Facilities, Second Edition

11. National Fire Protection Authority, 2013, Standard for the Production, Storage, and Handling of Liquefied Natural Gas (LNG) 
12. William Keller, Mohammad Modarres, 2005,_A historical overview of probabilistic risk assessment development and its use in the nuclear power industry: a tribute to the late Professor Norman Carl Rasmussen' Centre for Technology Risk Studies, 2100 Marie Mount Hall, University of Maryland, College Park, MA 20742 7531, USA

13. Clive Nussey, 2006, Clive Nussey - 2006 , Failure Frequency of Major Failures of High Pressure Storage Vessels at COMAH sites: A comparison of data used by HSE and the Netherlands, www.hse.gov.uk [Accessed on July 25 2015]

14. Canvey: an investigation of potential hazards from operations in the Canvey Island/Thurrock area, 1978, ISBN $0111883200 \mathrm{X}$

15. Rijnmond Public Authority, 1982, Risk Analysis of Six Potentially Hazardous Industrial Objects in the Rijnmond Area: A Pilot Study, ISBN 9789027713933

16. Health and Safety Executive, UK, Offshore Hydrocarbon Releases Statistics, 2002 on www.hse.hse.gov.uk

17. H.I. Beerens, , J.G. Post, P.A.M. Uijt de Haag,2006, The use of generic failure frequencies in QRA: The quality and use of failure frequencies and how to bring them upto-date, Journal of Hazardous Materials ,Volume 130, Issue 3, Pages 265-270

18. RIVM, CPR 18E, Guidelines for Quantitative Risk Assessment, 1st edition 1999, SDU Uitgevers, Den Haag, ISBN 90-12-08796-1, ISSN 0166-8935/2.10.0121/8804

19. Offshore Reliability Data (OREDA), 2002, Edition 4, ISBN-82-14-02705-5

20. Michael Moosemiller, 2006, Avoiding pitfalls in assembling an equipment failure rate database for risk assessments, Journal of Hazardous Materials ,Volume 130 (1-2) , Pages 128-132

21. DNV, 2013, Failure frequency guidance, Process equipment leak frequency data for use in $Q R A$

22. M.S. Mannan,2006, Harnessing Data Mining to Explore Incident Databases,” Journal of Hazardous Materials, vol. 130, no. 1-2, March 2006, pp. 33-41

23. R. Pitblado et al ,2011, Frequency Data and Modification Factors used in QRA Studies, Journal of Loss Prevention in the Process Industries, 8th World Congress of Chemical Engineering

24. VNTP - 3-85, Russian design standard

25. VUPP 88 - Russian design standard

26. Kevin B McGrattan et.al , 2000, Thermal Radiation from Large pool Fires, National Institute of Standards and Technology, NISTIR -6546 